

Photo by the late Dr. W. C. McCalla Many-spined Prickly Pear, Opuntia polyacantha Haw.

\title{
A Further Report of "Pink" Blue Beard-tongue
}

by W. S. Richards, Saskatoon

In reporting on a pink form of Blue Beard-tcngue (Penstemon nitidus Dougl.) found at Moose Jaw (Blue Jay, 18:132, Sept., 1960) the editcr wondered if any reader had noticed colour variations in this species.

On June 8, 1963, while on a botany - photcgraphy hike near Brcwn's Lake, about 10 miles southwest of Saskatcon, members and friends of the Saskatoon .Natural History Society were delighted when a young member found a beautiful pink Blue Beard-tongue growing on a sandy hillside. This plant, which was about 12 inches high, had three main stems, each stem having an inflorescence ccvering the top three inches. The colour was distinctly pink; other specimens nearby varied from blue to purplish and pinkish. No white-flowered specimens were seen. The pink-flowered plant quickly became the centre of interest for all the photographers, and many lingered to take extra "shots" after the main group had passed on.

The Slender Beard-tongue ( $P$. procerus Dougl.) and the Lilacflowered Beard-tongue ( $P$. gracilis Nutt.) were also both common in this area. Acccrding to J. H. Hudson we were just at the northern limit of the range of a fourth species, the White-flowered Beard-tongue ( $P$. albidus Nutt.) but we did not see any on this field trip.

Finding an unusual colour form in any native species always provides a pleasant surprise. In the vicinity cf Saskatoon I have noticed white varieties of the Spider Flower (Cleome serrulata Pursh) usually pink, Canada Thistle (Cirsium arvense (L.) Scop.) generally purple, and Blue Lettuce (Lactuca sp.) generally blue. I have also frequently found blueflowered specimens of Moss Phlox (Phlox hoodii Rich.) which is normally white. 